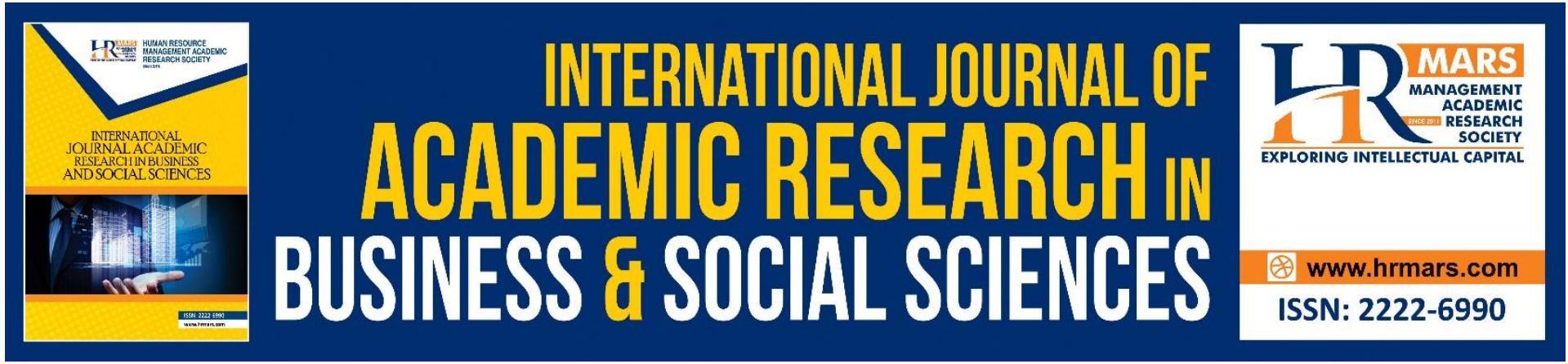

\title{
An Innovative Humanitarian Activities Mapping in Malaysia
}

Abdul Rauf Abdul Rasam, Sakinah Anisah Khairulannuar and Rosslina Mohamed Nawi

To Link this Article: http://dx.doi.org/10.6007/IJARBSS/v11-i6/10339 DOI:10.6007/IJARBSS/v11-i6/10339

Received: 18 April 2021, Revised: 20 May 2021, Accepted: 02 June 2021

Published Online: 26 June 2021

In-Text Citation: (Rasam et al., 2021)

To Cite this Article: Rasam, A. R. A., Khairulannuar, S. A., \& Nawi, R. M. (2021). An Innovative Humanitarian Activities Mapping in Malaysia. International Journal of Academic Research in Business and Social Sciences, 11(6), 1293-1306.

Copyright: @ 2021 The Author(s)

Published by Human Resource Management Academic Research Society (www.hrmars.com) This article is published under the Creative Commons Attribution (CC BY 4.0) license. Anyone may reproduce, distribute, translate and create derivative works of this article (for both commercial and non-commercial purposes), subject to full attribution to the original publication and authors. The full terms of this license may be seen at: http://creativecommons.org/licences/by/4.0/legalcode

Vol. 11, No. 6, 2021, Pg. 1293 - 1306

Full Terms \& Conditions of access and use can be found at http://hrmars.com/index.php/pages/detail/publication-ethics 


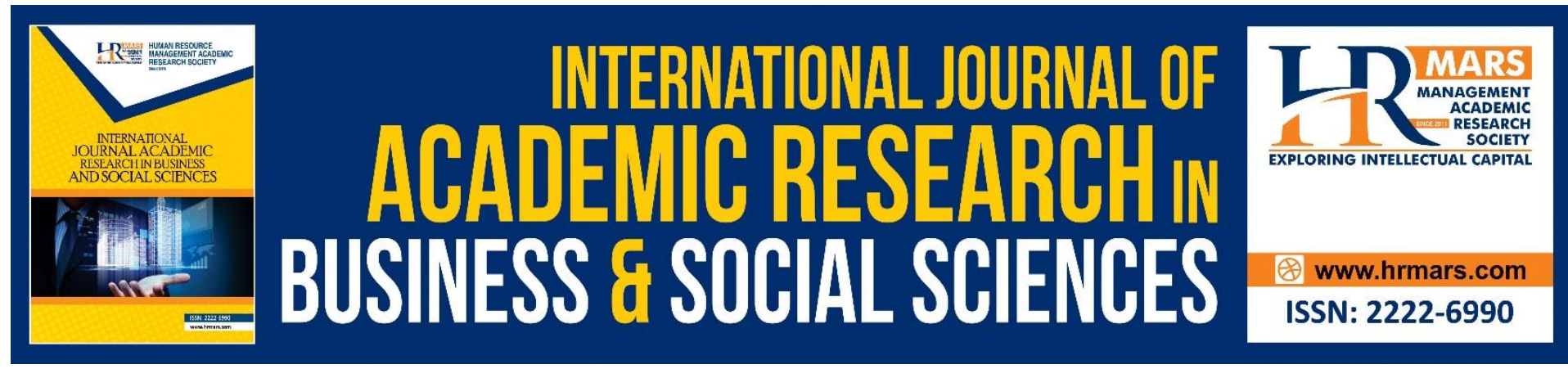

\title{
An Innovative Humanitarian Activities Mapping in Malaysia
}

\author{
Abdul Rauf Abdul Rasam ${ }^{1}$, Sakinah Anisah Khairulannuar ${ }^{2}$ and \\ Rosslina Mohamed Nawi ${ }^{3}$ \\ ${ }^{1,2}$ Centre of Studies for Surveying Science and Geomatics, Faculty of Architecture, Planning \\ and Surveying, Environmental and Social Health (ESH) Group, Health and Wellbeing \\ Excellence Entities, ${ }^{3}$ Web Media Division and Faculty of Computer and Mathematical \\ Sciences, Universiti Teknologi MARA, Shah Alam, Selangor, Malaysia. \\ Email: rauf@uitm.edu.my
}

\begin{abstract}
Many people register to be volunteers in many non-governmental organizations. However, the data is not fully utilized especially when there are events that require the volunteer immediately. This is due to the data that are not adequately managed. Therefore, this study is to develop a web-based multimedia mapping system for decision tool making and sharing geo-information on the volunteer program in Malaysia. This study has been conducted by using a standard development process that is known as Agile Models which has less strict guidelines and adjust according to needs in Standard Development Life Cycle (SDLC). The proposed volunteer management system can be accessed through https://volunteermanagement-learngis2.hub.arcgis.com/. This exciting system provides a basic information system such as database, query, mapping, measurement, buffering, and others related to the humanitarian program. Beta testing has been conducted for a user's satisfaction. The proposed volunteer management system should be able to increase the efficiency and effectiveness of an organization in handling the volunteer's database and humanitarian program in Malaysia.
\end{abstract}

Keywords: Volunteerism, Humanitarian, Web-Based Multimedia, GIS Mapping

\section{Introduction}

Malaysia appears to be moving forward in supporting the spirit of volunteerism. Even though in the USA volunteerism is on the decline, as shown in their 2014 data. The United States Bureau of Labor Statistics shows that volunteering was at a 10-year low. The US government intervened to stop this declining trend by implementing several initiatives. The nongovernmental organizations and volunteering public now has access to portals and websites set up to encourage more participation from the public. Winston Churchill, the British Politician once said that, we make a living by what we get, but we make a life by what we give. This is the quote that drives the whole volunteerism spirit of volunteers to achieve many good causes in the name of altruism (Lim, 2014). 
The people who volunteer are changing, based on the shifting of socio-economic and environmental trends. People contribute more to their communities informally based on structured volunteer programs. Another aspect of volunteerism relies on technology and better understanding of employers. For example, during disasters, volunteers are connected online and volunteering from their workplace with the encouragement of their employer. Volunteering remains an essential driver of political, social and economic development regardless of the form it takes. It is an instrumental force in promoting positive and sustainable growth for humanity (Witt, 2011).

Living in this digital age, the information technologies have gained importance due to their efficiency with low costs in the worldwide organizations. GIS is affected by data management systems as a development in computer and information systems. Data management is an important part of GIS. At the beginning phase of GIS, various data structures and exchanging different types of data cause serious problems. Data exchange still remains as one of the main problems even though organizations and individuals involved with GIS have developed many different solutions. The purpose of these solutions is to open up new perspectives of creating and managing data systems easily and economically even tough development of computers and data systems is linked with some problems.

Over the past few years, interactive mapping or Internet GIS has developed rapidly resulting in the migration of some GIS functionality. To facilitate the users involved in volunteer organizations, in terms of search, analysis, deployment, test and delivery a web-based mapping navigation interface system should be established. With the use of specialized GIS software, users can use the system applications by using internet browsing applications such as Internet Explorer, Mozilla Firefox or Google Chrome (Hazrin et al., 2014). Therefore, this study will result in the development of a web-based multimedia GIS application for volunteer's programme in Malaysia. Table 1 shows the previous process of the volunteer management system and summarized the volunteer management model from numerous versions. 
TABLE 1. Process of Volunteer Management (Mazlan, 2017)

\begin{tabular}{|c|c|c|c|c|c|}
\hline \multirow{2}{*}{$\begin{array}{c}\text { Autho } \\
r\end{array}$} & \multicolumn{5}{|c|}{ Process } \\
\hline & $\begin{array}{l}\text { Plann } \\
\text { ing }\end{array}$ & $\begin{array}{c}\text { Recrui } \\
\mathbf{t} \\
\text { ment } \\
\& \\
\text { Selecti } \\
0 \\
\mathrm{n}\end{array}$ & $\begin{array}{l}\text { Inductio } \\
\text { n \& } \\
\text { Training }\end{array}$ & $\begin{array}{c}\text { Supervisio } \\
n \quad \& \\
\text { Evaluation }\end{array}$ & $\begin{array}{c}\text { Recogni } \\
\text { tion }\end{array}$ \\
\hline $\begin{array}{l}\text { Zheng, } \\
\text { (2009) }\end{array}$ & / & / & 1 & $x$ & 1 \\
\hline $\begin{array}{c}\text { Duchar } \\
\text { me, } \\
(2012)\end{array}$ & 1 & / & 1 & 1 & / \\
\hline $\begin{array}{l}\text { VGO, } \\
(2010)\end{array}$ & I & $x$ & $x$ & / & 1 \\
\hline $\begin{array}{c}\text { Howar } \\
\text { d, } \\
(1999)\end{array}$ & 1 & / & / & 1 & 1 \\
\hline $\begin{array}{c}\text { VA, } \\
(2003)\end{array}$ & 1 & / & I & / & / \\
\hline $\begin{array}{l}\text { Studer } \\
\text { et. al, } \\
(2013)\end{array}$ & I & I & 1 & 1 & / \\
\hline
\end{tabular}

\section{Method}

\section{User Requirement}

An informal interview was conducted with one of the MyCARE staff, Sarah Afiqah binti Khairulannuar, Project Coordinator of MyCARE. Volunteers are really needed in order to make a program run smoothly. Even though they already provided a registration platform for those who are interested in becoming their volunteer, they don't have a system to manage the registered volunteers. Therefore, the database of these volunteers needs to be fully utilized so they can cut the time of recruiting the volunteer for their upcoming humanitarian program at a certain location. As a result, a potential customer, MyCARE, wants to have a web application which involves volunteer management. In this case, the requirement has to be clear about the volunteer criteria needed like what kind of skills, interest, involvement and at which location or state they would like to volunteer. The questionnaire has been distributed to the public.

\section{System Development}

Once the user requirements have been gathered, Web-based for volunteer management system can be developed.

- Identification of hardware and software 
Table 2 shows the list and specification required to design and develop the Web-Based GIS Application.

TABLE 2. List of Hardware and Software Specification

\begin{tabular}{l|l}
\hline \multicolumn{2}{l}{ List } \\
$\begin{array}{l}\text { Hardware } \\
\text { Acer Aspire }\end{array}$ \\
$\begin{array}{l}\text { E 14 } \\
\text { Processor: IntelBCore }{ }^{\text {TM }} \text { i5-7200U CPU @ } \\
\text { RAM: } 8.00 \mathrm{~GB} \\
\text { OS: Windows 10 } \\
\text { System Type: 64-bit }\end{array}$ \\
\hline $\begin{array}{l}\text { Software } \\
\text { ArcGIS }\end{array}$ & $\begin{array}{l}\text { A cloud-based GIS Mapping Platform } \\
\text { Online }\end{array}$ \\
\hline $\begin{array}{l}\text { ArcGIS } \\
\text { Hub }\end{array}$ & $\begin{array}{l}\text { An easy-to-configure cloud platform that } \\
\text { organizes people, data, and tools to } \\
\text { accomplish Initiatives and goals. }\end{array}$ \\
\hline $\begin{array}{l}\text { ArcGIS } \\
\text { Web App } \\
\text { Builder }\end{array}$ & $\begin{array}{l}\text { An intuitive what - you - see - is - what - } \\
\text { you - get (WYSIWYG) application that } \\
\text { allows to build 2D and 3D web apps } \\
\text { without writing a single line of code. It } \\
\text { includes powerful tools to configure fully } \\
\text { featured HTML apps. }\end{array}$ \\
\hline
\end{tabular}

\section{- $\quad$ System Design}

The new system has to be developed based on the user expectations and a thorough review of a new system. This is the process of designing the framework. This is the most critical step of a system 's growth. The logical design of the system came about as a result of the system analysis and is converted into physical design. Figure 1 is about the landing page of the main topic for the system. 


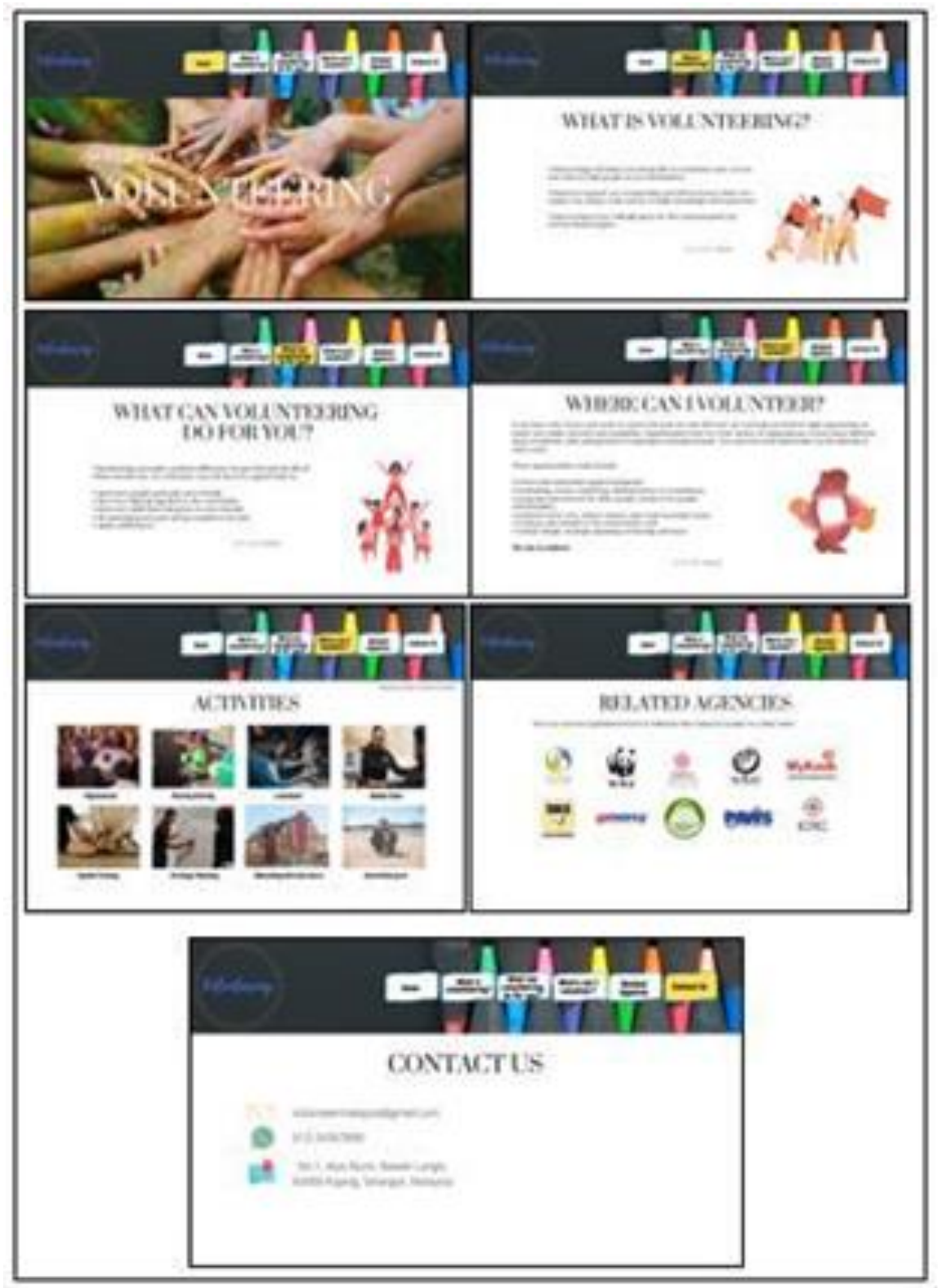

Fig 1: Volunteer Landing Page

Figure 2 illustrates one activity to another activity with logical decisions in activity diagram. This activity portrayed the system operation. 


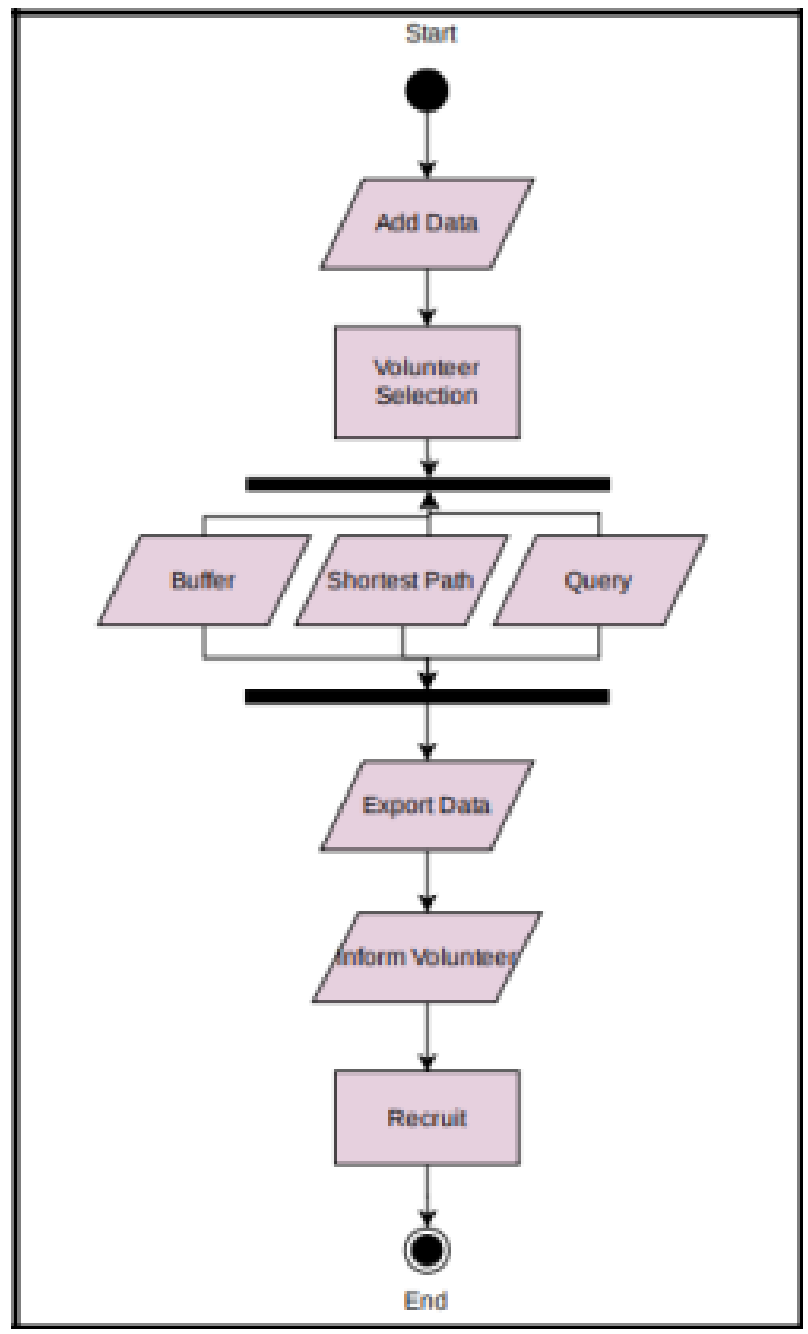

Fig 2: Activity Diagram

- $\quad$ System Implementation

This phase is an actual construction process after the illustrated design of the requested system is fully satisfied. Figure 3 is about developing process of Manage Volunteer Application, while Figure 4 shows the development of volunteer landing page 
INTERNATIONAL JOURNAL OF ACADEMIC RESEARCH IN BUSINESS AND SOCIAL SCIENCES Vol. 11, No. 6, 2021, E-ISSN: 2222-6990 @ 2021 HRMARS

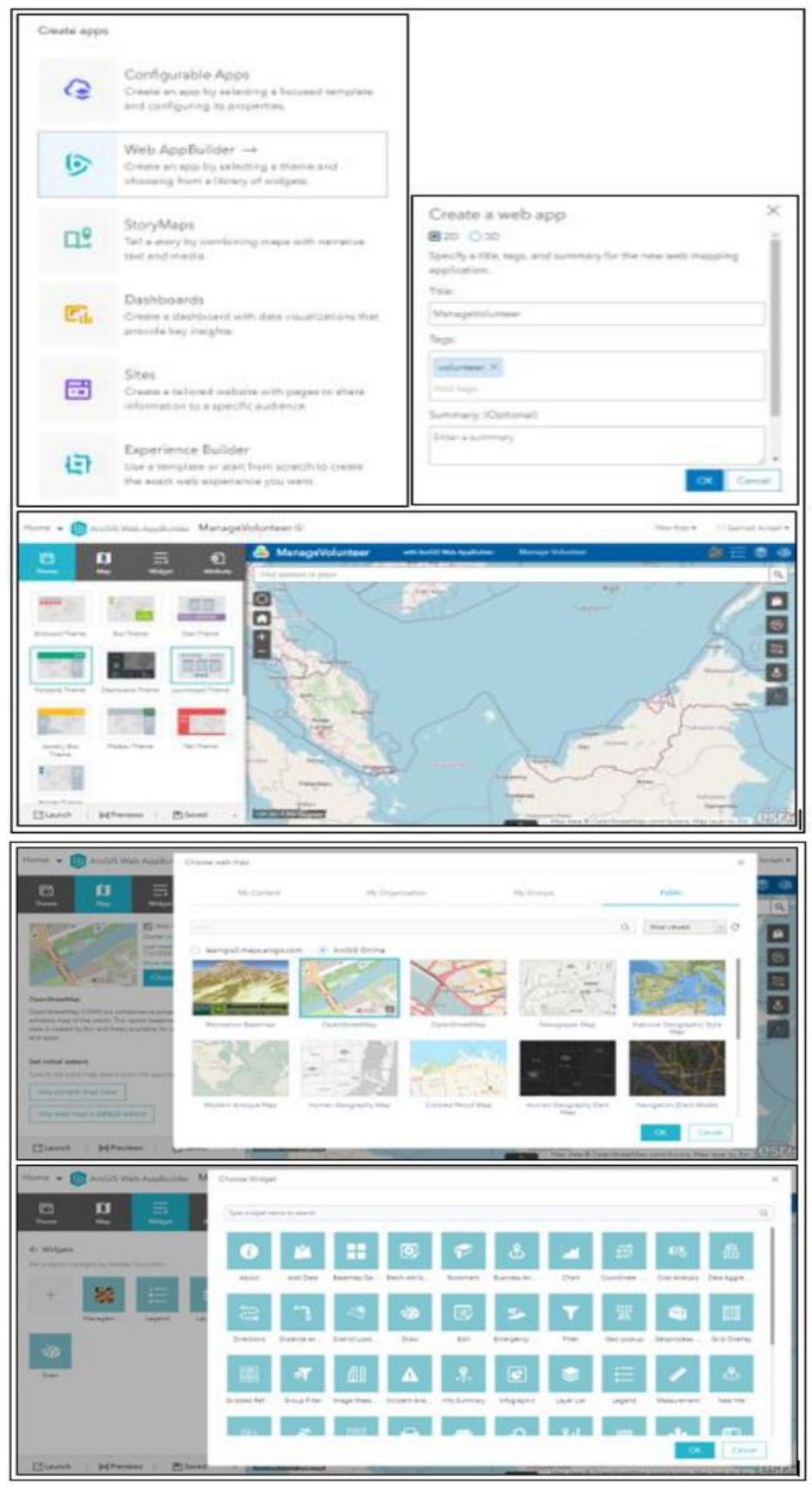

Fig 3: Development of Manage Volunteer Application 
INTERNATIONAL JOURNAL OF ACADEMIC RESEARCH IN BUSINESS AND SOCIAL SCIENCES Vol. 11, No. 6, 2021, E-ISSN: 2222-6990 @ 2021 HRMARS

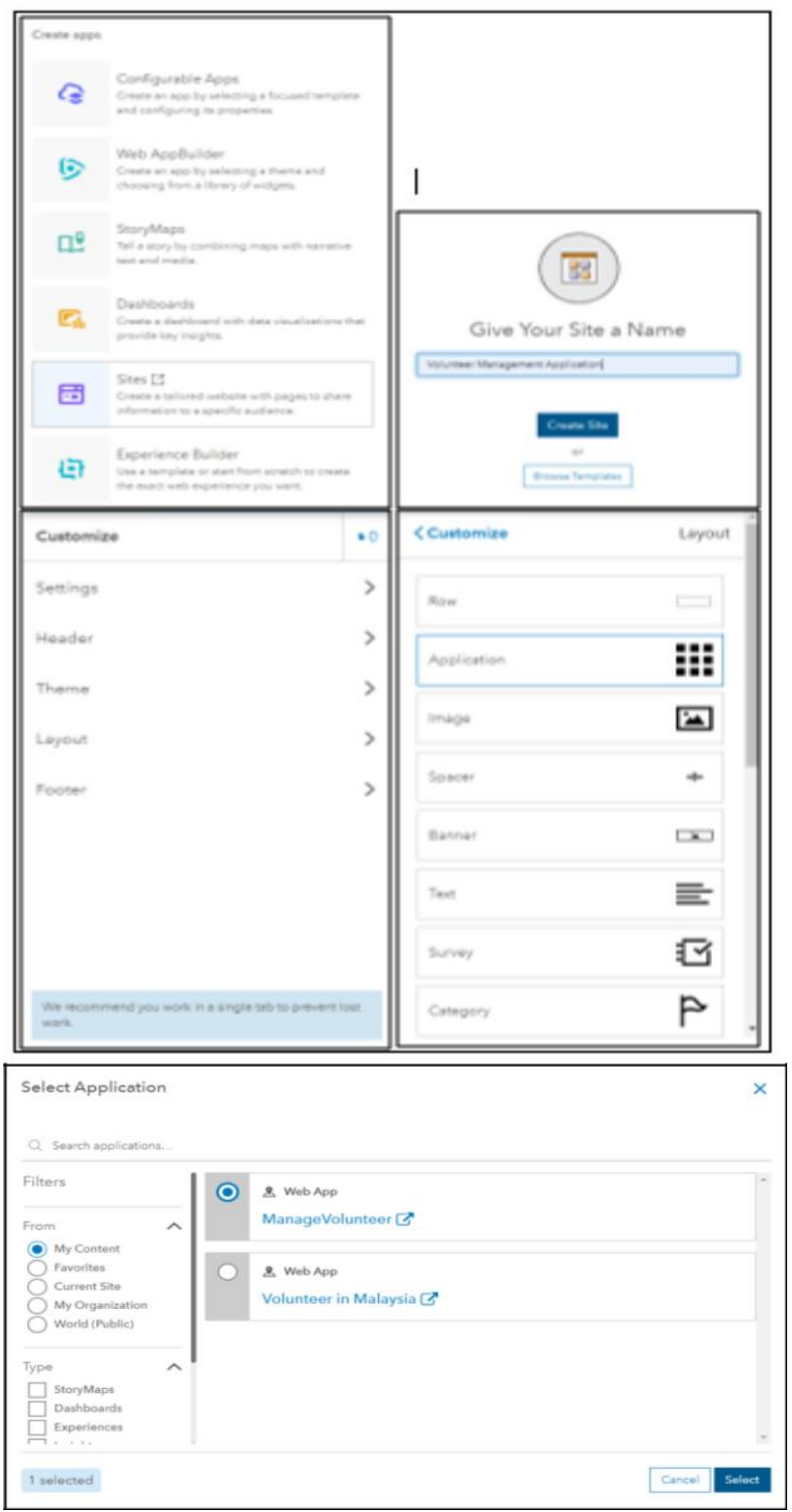

Fig 4: Development of volunteer landing page 


\section{System Testing}

Two types of testing were performed, which is alpha testing, to test the functionality of the system internally whereas beta testing is distributed to the actual users. The feedback and comments were gathered for further action.

\section{Results and Discussion}

The results discuss the output of the main objectives and the analysis will describe the motive of this study with the functionality of the proposed system.

\section{User Requirements}

The needs assessment was conducted by distributing the questionnaire to the public or potential volunteers via Google Form. The finding in user requirements is about the necessity of the volunteer system in their activity. $93.8 \%$ of the respondents agreed that there is the need to have a system for volunteers. The elements needed in the system are map, volunteer database, tracking performance and calendar activities. The respondent suggested having the verification of registered volunteers and providing training for them.

\section{Framework and Functions of the Proposed System}

This web-based GIS application consists of a website and volunteer management system. It started with website of the volunteer website to share the general information about volunteering. Then a person from the organization will be assigned as an administrator to manage. This website can be accessed publicly by entering this web address: https://volunteer-management-learngis2.hub.arcgis.com/ in any type of search engine and device.

Figure 5 shows the website page and Figure 6 until Figure 8 shows the GIS application for the volunteer management system.

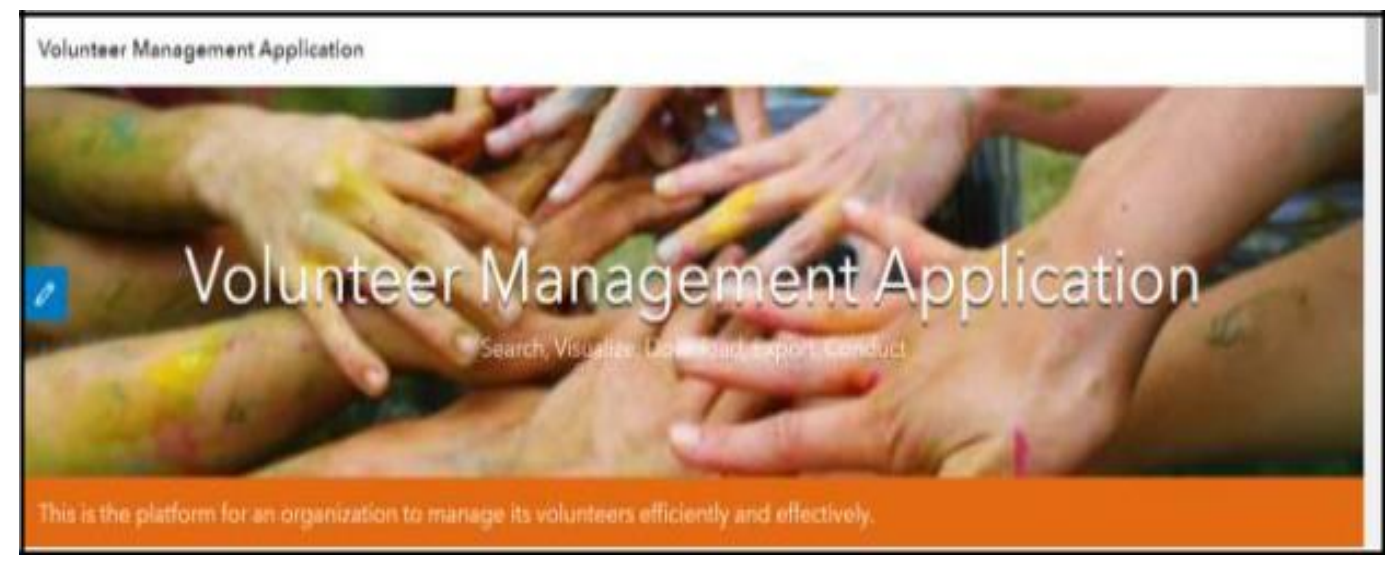

Fig 5: Website Main Page 


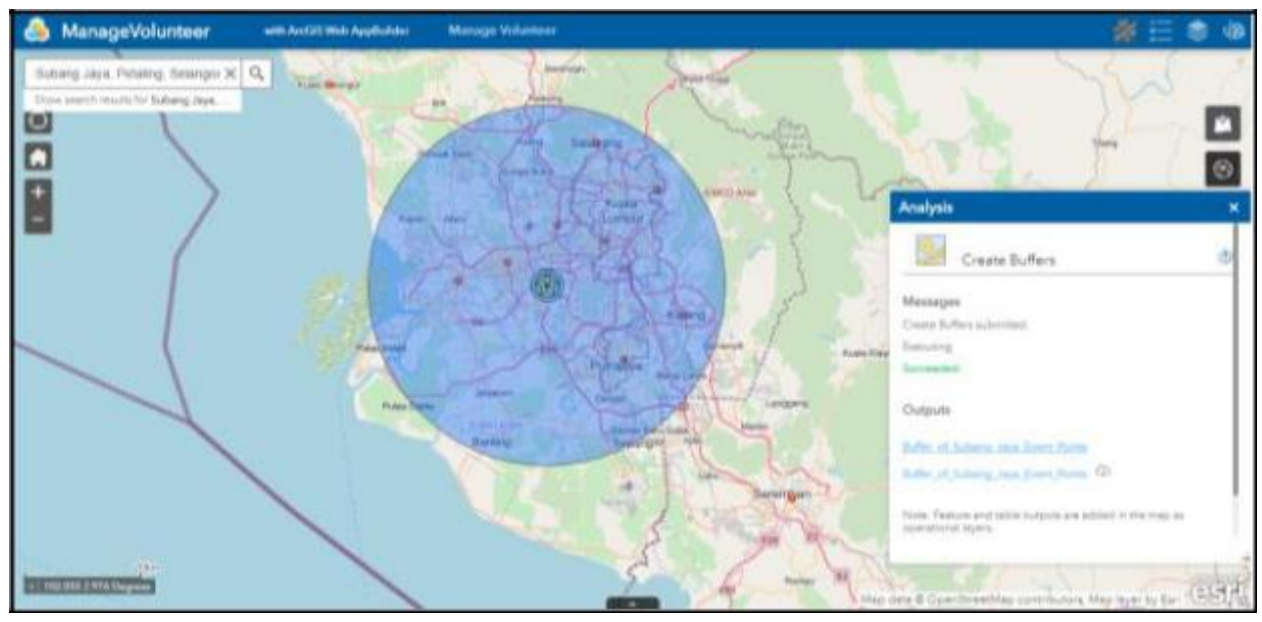

Fig 6: Function of Buffer

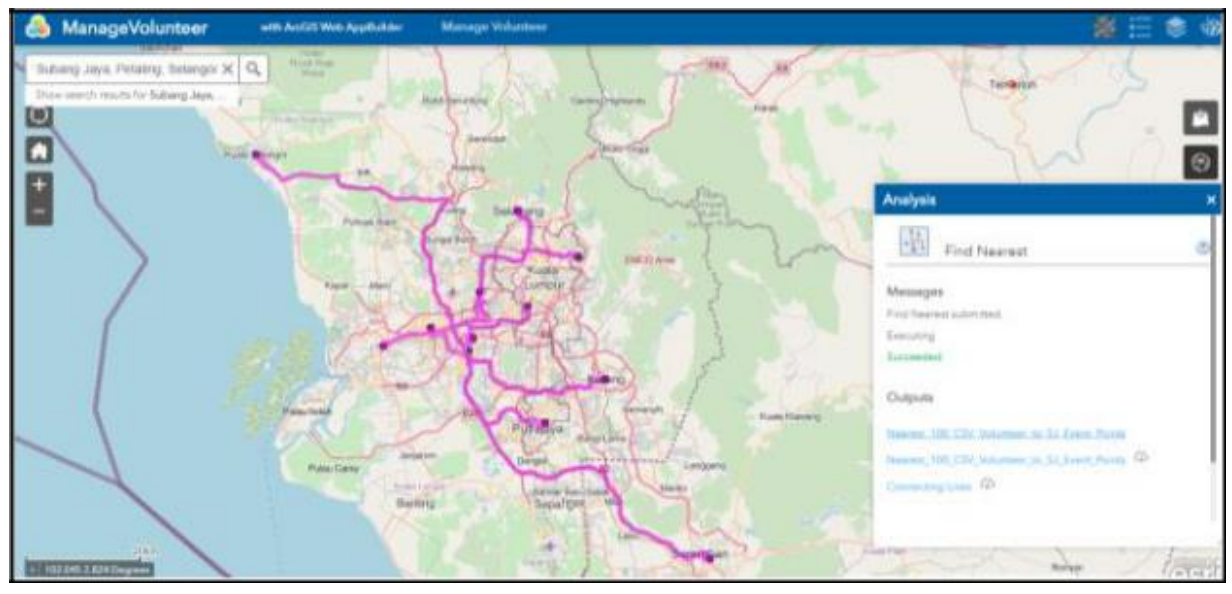

Fig 7: Function of Network

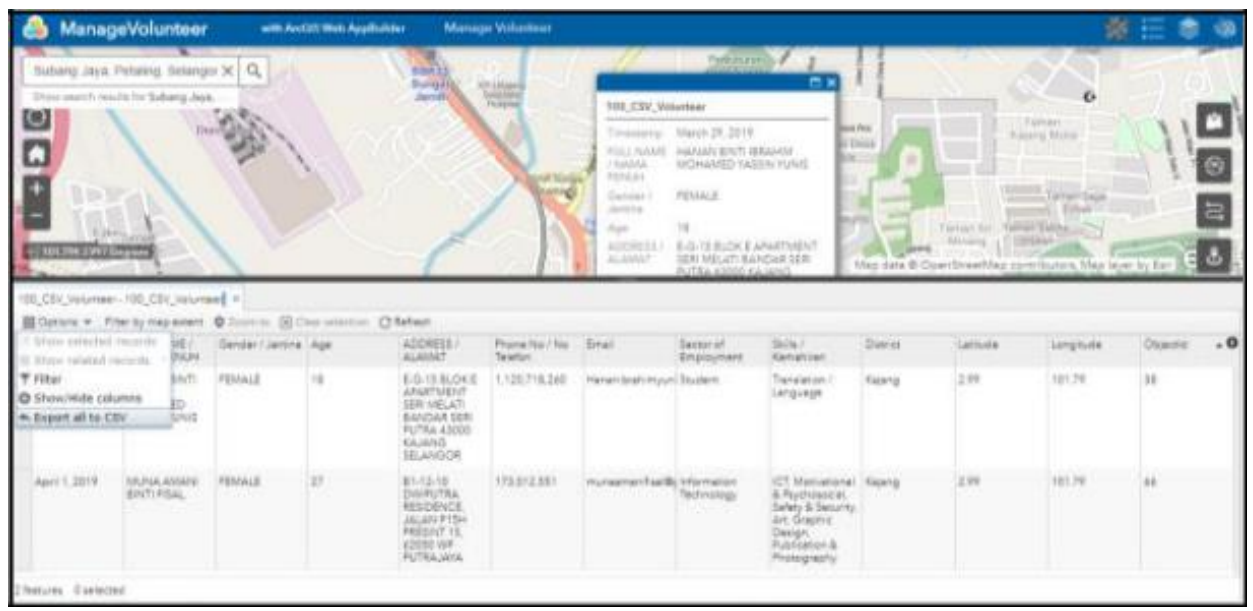

Fig 8: Function of Query

\section{System Testing}

In general, all of the users are satisfied in terms of the website content, system design, system usability and reliability of the system. The administrator agreed that this proposed volunteer management system is convenient, efficient, increases productivity and enthusiasm of 
volunteers, reliable and easy to understand. Therefore, this testing is able to make the developer see the real-response and do some correction.

\section{Conclusion}

Overall, this system of Web-Based Multimedia GIS Application has been successfully developed. The system can generate the volunteer's information needed by an organization related to volunteering activities. The existence of this proposed volunteer management system would be an effective tool and increase the efficiency and effectiveness of an organization in handling the volunteer's database.

\section{Acknowledgements}

The authors gratefully acknowledge the help of the Universiti Teknologi MARA Selangor for providing LESTARI Research Fund (600-IRMI5/3/LESTARI (005/2018). The authors are also thankful to the Humanitarian Care Malaysia (MyCARE), willing to provide meaningful information along the development process to achieve this study.

\section{References}

Abdalla, R. (2016). Evaluation of spatial analysis application for urban emergency management. SpringerPlus, 5(1). Retrieved from https://doi.org/10.1186/s40064-0163723-y

Ahmad, A. T. (2017). Making a difference: Talk, eat, sleep, love volunteerism I New Straits Times I Malaysia General Business Sports and Lifestyle News. Retrieved from https://www.nst.com.my/opinion/columnists/2017/11/304822/making-differencetalk-eat-sleep-love-volunteerism

Alex, G. K. (2005). Successful Strategies for Recruiting, Training, and Utilizing Volunteers: A Guide for Faith-and Community-Based Service Providers. U.S. Department of Health and Human Services (DHHS). Retrieved from http://www.ncjrs.gov/App/publications/Abstract.aspx?id=209809

Alfes, K., Shantz, A., Bailey, C. (2016). Enhancing volunteer engagement to achieve desirable outcomes: What can non-profit employers do?. Voluntas 27, 2, 595-617

Allen, J. A., Mueller, S. L. (2013). The revolving door: A closer look at major factors in volunteers' intention to quit. Journal of Community Psychology 41, 2, 139-55, doi:10.1002/jcop.21519

Bokhari, M. U., Siddiqui, S. T., \& Alam, M. S. (2011). Web-Based GIS Softwares and its Applications: A Comparative Study. The Geographer, 58. Retrieved from https://www.academia.edu/2050923/Web-

Based_GIS_Softwares_and_its_Applications_A_Comparative_Study

Cheng. (2013). More young people take to volunteerism - TODAYonline. https://www.todayonline.com/singapore/more-young-people-take-volunteerism

Cinnamon, J. (2020). Humanitarian Mapping. In International Encyclopedia of Human Geography (pp. 121-128). Elsevier. https://doi.org/10.1016/b978-0-08-1022955.10559-1

Dodd, C., \& Boleman, C. (2010). Volunteer Administration in the 21 st Century : ISOTURE : A Model for Volunteer Management.

http://agrilifecdn.tamu.edu/od/files/2010/06/Isoture-model-for-volunteermanagement-E-457.pdf 
DSG. (2012). How big is volunteering in Malaysia? | Do Something Good. Retrieved November 23, 2019, from https://www.dosomething.gd/volunteering-in-malaysia-the-bigpicture/

Ducharme E. G. (2012). Our Foundation - The Basics of Volunteer Management. Can. J. Volunt. Resour. Manag. No. 20.1. 2-4

Einolf, C. (2018). Evidence-based volunteer management: A review of the literature. In Voluntary Sector Review (Vol. 9, Issue 2, pp. 153-176). Policy Press. https://doi.org/10.1332/204080518X15299334470348

Erasmus, B., Morey, P. J. (2016). Faith-based volunteer motivation: Exploring the applicability of the Volunteer Functions Inventory to the motivations and satisfaction levels in an Australian faith-based organization, Voluntas 27, 3, 1343-60

Ezin, E. C., \& Akakpo, A. J. (2013). Web Mapping System for Public Area Management in Developing Countries. 2(1), 9-20. https://doi.org/10.5923/j.web.20130201.02

Fényes, H., \& Pusztai, G. (2012). Volunteering among higher education students. Focusing on the micro-level factors. Journal of Social Research and Policy, 3(1), 73-95.

Hazrin, H., Tahir, A., \& Fadhli, Y. (2014). Implementation of Web based GIS Application for Mapping of Health Facilities, Services and Providers in Malaysia. Global Journals Inc. (USA), 14(5), 46-50. Retrieved from

https://www.researchgate.net/publication/279798295_Implementation_of_Web_bas ed_GIS_Application_for_Mapping_of_Health_Facilities_Services_and_Providers_in_M alaysia

Hager, M. A., Brudney, J. L. (2015). In search of strategy: Universalistic, contingent, and configurational adoption of volunteer management practices. Nonprofit Management and Leadership 25, 3, 235-54

Dustin, H. M., Kirk, B. L. E. H. K. (2017). Evaluating Volunteer Competencies to Achieve Organizational Goals. International Journal of Volunteer Administration, 53(9), 35-49. https://doi.org/10.1017/CBO9781107415324.004

Howard, B. W. (1999). Managing volunteers. Australian Journal of Emergency Management. Vol. 14, No. 3. 37-39. Retrieved from http://www.austlii.edu.au/au/journals/AUJIEmMgmt/1999/39.pdf

Cheng, K. (2013). More young people take to volunteerism - TODAYonline. Retrieved November 23, 2019, from https://www.todayonline.com/singapore/more-youngpeople-take-volunteerism

Lim, C. W. (2014). 10 ways to contribute to a good cause | The Star Online. Retrieved September 30, 2019, from The Star Online website:

https://www.thestar.com.my/news/community/2014/12/06/10--ways-to-contributeto-a-good-cause

Mapaction. (2011). Field Guide to Humanitarian Mapping Second Edition , 2011 This field guide was produced by MapAction to help humanitarian organisations to make use of mapping methods using Geographic Information Systems ( GIS ) and related technologies . Information Systems, Edition, S.

Mazlan, N., Ahmad, S. S. S., Kamalrudin, M., \& Bakar, A. Z. A. (2017). A crowd sourcing approach for volunteering system. COMPSE 2016 - 1st EAI International Conference on Computer Science and Engineering. https://doi.org/10.4108/eai.27-2-2017.152253

Mohd, S., Fathi, S. M., \& Harun, N. A. (2019). Information management for humanitarian aid distribution system in Malaysia. IOP Conference Series: Materials Science and Engineering, 513(1). https://doi.org/10.1088/1757-899X/513/1/012012 
Muehlenhaus, I. (2014). Web Cartography - Map Design for Interactive and Mobile Devices. CRC Press.

Nencini, A., Romaioli, D., Meneghini, A. M. (2016). Volunteer motivation and organizational climate: Factors that promote satisfaction and sustained volunteerism in NPOs, Voluntas 27, 618-39

NHMRC. (2003). Working with Volunteers and Managing Volunteer Programs in Health Care Settings. Retrieved from https://www.volunteeringaustralia.org/wpcontent/files_mf/1377053104VAManagersworkingwithvolunteersandmanagingvolunt eerprogramsinhealthcaresettings.pdf

$\varnothing$ sterlund, K. (2013). Managing voluntary sport organizations to facilitate volunteer recruitment. European Sport Management Quarterly 13, 2, 143-65

Ozdilek, O., \& Seker, D. Z. (2015). A Web-Based Application for Real-Time GIS. (December 2008).

Paulsen, B. E. (2019). The future for refugees in Malaysia. Retrieved September 23, 2019, from The Star Online website: https://www.thestar.com.my/news/nation/2019/06/16/thefuture-for-refugees-in-msia

Studer, S. (2015). Volunteer management: Responding to the uniqueness of volunteers. Nonprofit and Voluntary Sector Quarterly, online first, http://journals.sagepub.com/doi/abs/10.1177/0899764015597786

Studer, S., \& Von Schnurbein, G. (2013). Organizational Factors Affecting Volunteers: A Literature Review on Volunteer Coordination. Voluntas. Vol. 24. No. 2. 403-440

UNHCR. (2017). Introduction To Mapping and Gis For Humanitarian Use.

Van Schie, S., Guntert, S. T., Oostlander, J., Wehner, T. (2015). How the organizational context impacts volunteers: A differentiated perspective on self-determined motivation, Voluntas 26, 1570-90

Volunteer Glasgow. (2010). Glasgow's Strategic Volunteering Framework.

Peter, W. G., Daniel, M. G. (2009). Shaping the Humanitarian World. Retrieved from https://books.google.com.my/books?hl=en\&lr=\&id=I_iSAgAAQBAJ\&oi=fnd\&pg=PP1\&d $q=$ humanitarian+\%2B\%2B2014\&ots=WnBvooy2nS\&sig=9aFkEVZF1bfaiQONHzBApAZf2 Kc\&redir_esc=y\#v=onepage \&q\&f=false

Witt, C. L. (2011). The value of volunteers. In Advances in Neonatal Care (Vol. 11). https://doi.org/10.1097/ANC.0b013e318207ff95

Yisong, Z. L., Deng, L., and Meiling, L. (2009). Study on the Event Volunteer Management Based on the Service Blueprint. International Conference on Information Management, Innovation Management and Industrial Engineering. 408-411. 